\title{
Peran Kepala Sekolah, Guru, dan Alumni dalam Pengembangan Jiwa dan Kemampuan Kewirausahaan Siswa
}

\author{
Hapsari Dwi Marta Lita*, Maisyaroh, Juharyanto \\ Universitas Negeri Malang, Jl. Semarang No. 5 Malang, Jawa Timur, Indonesia \\ *Penulis korespondensi, Surel: hapsaridm97@gmail.com
}

Paper received: 7-6-2021; revised: 21-6-2021; accepted: 28-6-2021

\begin{abstract}
This study aims to describe: (1) the strategies of principals, teachers, and alumni in developing the entrepreneurial spirit of students; (2) strategies of principals, teachers, and alumni in developing student's entrepreneurial abilities; (3) the role of principals and teachers in the implementation of a double track learning system; (4) alumni participation in the implementation of learning entrepreneurship practices for students; (5) constrains encountered in developing student's entrepreneurial spirit and abilities; and (6) solutions to overcome the constraints to the development of entrepreneurial motivation and capacities. This research method used qualitative approach with a case study design data would collected through observation, interview, and documentation techniques. Based on the research data it can be concluded that principals, teachers, and alumni have several strategies in developing the spirit and entrepreneurial abilities of students. The strategy includes requiring students to go directly into school entrepreneurship activities, providing material related to entrepreneurship practices, implement literacy programs to develop, brainstorm, and create dream books. In addition, principals and teachers play a role as policy makers in the implementation of double track learning policies. Alumni also actively participate in the implementation of entrepreneurship practice learning. The constraints experienced by principals, teachers, and alumni in developing spirit and entrepreneurial abilities are the students have low awareness and confidence. These constraints can be overcome by providing motivation, assistance, and student insight.
\end{abstract}

Keywords: role; entrepreneurial soul; entrepreneurial ability

\begin{abstract}
Abstrak
Penelitian ini bertujuan untuk mengetahui: (1) strategi kepala sekolah, guru, dan alumni dalam pengembangan jiwa kewirausahaan siswa; (2) strategi kepala sekolah, guru, dan alumni dalam pengembangan kemampuan kewirausahaan siswa; (3) peran kepala sekolah dan guru dalam penerapan sistem pembelajaran double track; (4) partisipasi alumni dalam pembelajaran praktik kewirausahaan siswa; (5) hambatan kepala sekolah, guru, dan alumni dalam mengembangkan jiwa dan kemampuan kewirausahaan siswa; dan (6) solusi kepala sekolah, guru, dan alumni dalam mengatasi hambatan pengembangan jiwa dan kemampuan kewirausahaan siswa. Metode penelitian ini menggunakan pendekatan kualitatif jenis studi kasus dengan teknik observasi, wawancara, dan dokumentasi. Berdasarkan data penelitian dapat disimpulkan bahwa kepala sekolah, guru, dan alumni memiliki beberapa strategi dalam pengembangan jiwa dan kemampuan kewirausahaan siswa. Strategi tersebut diantaranya adalah mewajibkan siswa terjun langsung dalam kegiatan kewirausahaan sekolah, pemberian materi yang berkaitan dengan praktik kewirausahaan, penerapan program literasi buku pengembangan, curah pendapat, dan pembuatan dream book. Selain itu kepala sekolah dan guru berperan sebagai pembuat kebijakan dan pelaksanaan kebijakan pembelajaran dengan sistem double track. Alumni juga berpartisipasi aktif dalam pelaksanaan pembelajaran praktik kewirausahaan siswa. Hambatan yang dialami kepala sekolah, guru, dan alumni dalam pengembangan jiwa dan kemampuan kewirausahaan siswa adalah kesadaran siswa dan tingkat kepercayaan diri siswa. Hambatan tersebut dapat diatasi dengan pemberian motivasi, pendampingan berkelanjutan, serta membuka pemikiran para siswa.
\end{abstract}

Kata kunci: peran; jiwa kewirausahaan; kemampuan kewirausahaan 


\section{Pendahuluan}

Kepala sekolah, guru, dan alumni memiliki peran penting dalam mengembangkan jiwa dan kemampuan kewirausahaan siswa. Perkembangan zaman menuntut segala aspek kehidupan manusia ikut berkembang pula. Berbagai inovasi terus diciptakan demi mengikuti perkembangan zaman. Manusia dituntut untuk menjadi sumber daya yang kreatif, salah satu faktor yang menjadi penentu perkembangan sumber daya manusia adalah pendidikan. Pendidikan saat ini tidak hanya menuntut siswa untuk menguasai teori saja melainkan juga memiliki kemampuan kecakapan hidup atau life skill. Salah satu cara agar siswa mendapatkan kemampuan kecakapan hidup adalah dengan menerapkan pendidikan berbasis kewirausahaan. SMA Selamat Pagi Indonesia (SPI) Kota Batu merupakan salah satu sekolah yang menerapkan pendidikan berbasis kewirausahaan. SMA SPI memberikan fasilitas berupa laboratorium kewirausahaan yang terdiri dari beberapa divisi wirausaha sebagai wadah untuk siswa dalam mengembangkan diri.

Siswa tidak hanya diwajibkan menguasai teori tetapi juga harus mampu menerapkannya di kehidupan sosial. Salah satu cara yang dapat digunakan agar siswa dapat menerapkan ilmunya di kehidupan sosial adalah dengan penerapkan pendidikan berbasis kewirausahaan (Hakim, 2010). Pembentukan jiwa kewirausahaan umumnya banyak ditemukan pada pendidikan kejuruan. Sesuai dengan Peraturan Pemerintah Nomor 19 Tahun 2017 tentang Perubahan Atas Peraturan Pemerintah Nomor 74 Tahun 2008 tentang Guru pasal 1 ayat 22 yang berbunyi "Sekolah Menengah Kejuruan yang selanjutnya disingkat SMK adalah salah satu bentuk satuan pendidikan formal yang menyelenggarakan pendidikan kejuruan pada jenjang Pendidikan Menengah sebagai lanjutan dari SMP, MTs, atau bentuk lain yang sederajat atau lanjutan dari hasil belajar yang diakui sama atau setara SMP atau MTs". Sistem pendidikan yang ada di SMK mempersiapkan peserta didik agar memiliki kemandirian dan keahlian tertentu yang dapat digunakan untuk bekerja. Namun seiring berkembangnya zaman dimana setiap individu dituntut untuk selalu berinovasi, penanaman jiwa kewirausahaan saat ini tidak hanya diterapkan pada sekolah kejuruan saja tetapi juga sekolah umum. Hal ini diperkuat dengan kebijakan pada Kurikulum 2013 dimana pendidikan prakarya dan kewirausahaan diajarkan pada semua siswa SMA, MA, dan SMK (Kompas, 27 Februari 2013). Jika semula pendidikan kewirausahaan yang diajarkan di SMA atau MA masih berupa teori maka sesuai dengan Kurikulum 2013 siswa SMA dan MA juga mendapatkan kesempatan yang sama dengan siswa SMK.

Pendidikan kewirausahaan saat ini sudah mulai diterapkan di sekolah menengah atas. Penelitian yang dilakukan oleh Fauzi dan Trihantoyo (2016) mendukung pernyataan tersebut karena penelitian dilakukan di salah satu SMA berbasis kewirausahaan. Hasil penelitian Usman dan Raharjo (2012) yang menyatakan bahwa model implementasi pendidikan karakter kewirausahaan dilakukan melalui beberapa pendekatan yaitu keteladanan, pembelajaran di kelas dan luar kelas, pembudayaan melalui kultur sekolah, dan penguatan mendukung data studi pendahuluan peneliti di SMA Selamat Pagi Indonesia namun terdapat beberapa tambahan, dimana SMA Selamat Pagi Indonesia memiliki kriteria penilaian PAKSA (Pray, Attitude, Knowledge, Skill, Action) yang berarti dalam metode penilaian sekolah mengedepankan akhlak, sikap, pengetahuan, keterampilan, dan praktik siswa selama di lapangan.

Hasil penelitian yang dilakukan oleh Chotimah (2015) memaparkan bahwa proses pendidikan kewirausahaan di pondok pesantren Sidogiri dimulai dengan menjalankan 
sumber-sumber ekonomi pondok karena dengan menjalankan sumber ekonomi pondok siswa dapat menerapkan nilai kemandirian dan pengembangan life skill yang dimiliki. Penelitian tersebut memiliki persamaan dengan data yang diperoleh peneliti dari studi pendahuluan di SMA Selamat Pagi Indonesia karena SMA Selamat Pagi Indonesia juga menjalankan sumbersumber ekonomi sekolah sebagai salah satu sarana bagi siswa untuk melatih kemandirian dan kemampuan kewirausahaan siswa. Penelitian Fauzi dan Trihantoyo (2016) turut mendukung hasil studi pendahuluan dengan memberikan hasil bahwa terdapat program unggulan kewirausahaan di lokasi penelitian mereka. Hasil penelitian tersebut memiliki beberapa persamaan dengan studi pendahuluan yang dilakukan oleh peneliti di SMA Selamat Pagi Indonesia. SMA SPI memiliki program untuk memamerkan produk kewirausahaan bahkan memasarkannya, selain itu yang menjadikan berbeda adalah adanya campur tangan langsung dari alumni sebagai ketua divisi masing-masing program kewirausahaan yang ada di sekolah. Alumni sebagai pihak yang memberikan pengajaran mengenai praktik kewirausahaan siswa di SMA Selamat Pagi Indonesia.

Dalam mengembangkan jiwa dan kemampuan kewirausahaan siswa tentu terdapat peran kepala sekolah, guru, maupun pihak lain yang turut membantu tercapainya tujuan sekolah. Fauzi dan Trihantoyo (2016) menjelaskan bahwa kepala sekolah sebagai pemimpin pembelajaran berperan dalam perencanaan, pelaksanaan, dan evaluasi pembelajaran sekolah berbasis kewirausahaan. Jiwa wirausaha sangat penting untuk diterapkan pada siswa sedini mungkin. Melalui pengembangan karakter jiwa kewirausahaan diharapkan akan dapat merubah pola pikir peserta didik bahwa tidak selamanya setelah lulus dari bangku sekolah tidak harus melamar pekerjaan namun bisa menciptakan lapangan pekerjaan bagi orang lain untuk menjalankan usahanya tersebut (Sulistyowati \& Salwa, 2016). Khususnya pada jenjang menengah atas, pendidikan kewirausahaan tidak hanya diterima oleh siswa SMK saja melainkan juga siswa SMA dan MA.

Peneliti memilih SMA Selamat Pagi Indonesia (SPI) karena, sekolah ini merupakan sekolah menengah atas swasta di Kota Batu yang membebaskan siswanya dari segala beban biaya pendidikan. SMA Selamat Pagi Indonesia yang didirikan tahun 2007 ini pada prinsipnya mengedepankan anak-anak Indonesia pada jenjang SMA yang memiliki permasalahan ekonomi untuk melanjutkan pendidikan. SMA Selamat Pagi Indonesia memprioritaskan anak yatim piatu dan kurang mampu yang diseleksi dari seluruh Indonesia dengan agama yang berbeda. SMA Selamat Pagi Indonesia tidak memungut biaya sama sekali bahkan untuk kebutuhan siswa seperti buku, seragam, fasilitas asrama, hingga kebutuhan pribadi peserta didik. Sekolah juga memberikan uang saku pada peserta didik setiap bulannya sebagai apresiasi atas kemauan belajar peserta didik. Jika umumnya bantuan berupa beasiswa diterima oleh siswa tidak mampu dan memiliki kemampuan kognitif tinggi, maka SMA Selamat Pagi Indonesia mengedepankan siswa tidak mampu dan memiliki kemampuan kognitif rendah. Sehingga diharapkan siswa tersebut dapat mengembangkan diri pada aspek kewirausahaan seperti yang telah diterapkan di sekolah. SMA Selamat Pagi Indonesia juga dikenal sebagai sekolah wisata edukasi karena dalam sekolah tersebut terdapat laboratorium entrepreneur dan lifeskill yang disebut sebagai Transformer Center.

\section{Metode}

Penelitian ini menggunakan pendekatan kualitatif dengan jenis studi kasus, data-data yang ada mengkaji peran kepala sekolah, guru, dan alumni dalam pengembangan jiwa dan kemampuan kewirausahaan siswa SMA Selamat Pagi Indonesia Kota Batu. Moleong (2011) 
menyatakan bahwa penelitian kualitatif merupakan penelitian yang digunakan untuk memahami fenomena yang dialami tentang subjek penelitian seperti perilaku, persepsi, motivasi, dan tindakan. Penelitian ini bertujuan untuk mengungkapkan peran kepala sekolah, guru, dan alumni dalam pengembangan jiwa dan kemampuan kewirausahaan siswa. Sesuai dengan tema tersebut penelitian ini cenderung mengarah pada proses, sehingga perlu adanya informasi secara mendalam. Sesuai dengan pendapat Ulfatin (2015) bahwa dalam penelitian kualitatif fokus penelitian lebih banyak mencakup proses. Jenis penelitian yang digunakan oleh peneliti adalah studi kasus karena penelitian ini dilakukan di satu lokasi yang memiliki keunikan dan hal-hal yang perlu diteliti.

Kehadiran peneliti di lapangan merupakan instrumen kunci untuk melakukan pengumpulan data. Teknik pengumpulan data yang digunakan peneliti adalah dengan menggunakan metode observasi, wawancara, dan dokumentasi. Data yang telah terkumpul kemudian dianalisis menggunakan reduksi sesuai kode yang telah dibuat oleh peneliti, kemudian data disajikan dan ditarik kesimpulan. Untuk memperoleh keabsahan data, peneliti menggunakan salah satu dari empat kriteria yaitu keterpercayaan dengan teknik triangulasi sumber, pengecekan anggota, kecukupan bahan referensi.

\section{Hasil dan Pembahasan}

\subsection{Hasil}

Strategi kepala sekolah dalam mengembangkan jiwa kewirausahaan siswa meliputi pemberian motivasi, sharing, penerapan program literasi, evaluasi rutin dan melakukan pendekatan kekeluargaan dengan siswa. Sedangkan guru memiliki strategi penyisipan nilai kewirausahaan pada mata pelajaran, mengajar dengan membesarkan hati siswa, dan turut serta memberikan perhatian pada kegiatan kewirausahaan siswa. Para alumni memiliki strategi pendekatan mendalam pada setiap siswa, berupaya untuk selalu menyentuh hati siswa, dan penguatan impian siswa melalui dream book atau buku impian yang dimiliki masing-masing siswa yang berisi tentang mimpi dan target siswa dalam memperoleh sesuatu.

Strategi kepala sekolah dalam mengembangkan kemampuan kewirausahaan siswa adalah dengan melibatkan siswa dalam seluruh kegiatan praktik kewirausahaan dan pemberian fasilitas berupa beberapa jenis divisi usaha di laboratorium. Guru memiliki strategi pemberian materi pembelajaran yang berkaitan dengan kegiatan kewirausahaan, pemberian contoh-contoh nyata, dan penerapan SEL (Student Experiential Learning). Sedangkan alumni memiliki strategi mengajarkan ilmu-ilmu kewirausahaan sesuai dengan divisi, menggali bakat dan minat siswa, serta selalu berdiskusi dengan kepala sekolah dan guru mengenai perkembangan kemampuan kewirausahaan siswa. Contoh kegiatan kewirausahaan yang dilakukan di SMA Selamat Pagi Indonesia dapat dilihat pada Gambar 1.

Peran kepala sekolah dalam penerapan pembelajaran dengan sistem double track adalah pemberian kebijakan penerapan dua jenis pembelajaran yaitu $30 \%$ theory class dan $70 \%$ practice class, kepala sekolah juga bekerja sama dengan alumni untuk memberikan pembelajaran praktik pada siswa. Sedangkan guru berperan dalam penyisipan nilai-nilai kewirausahaan pada setiap mata pelajaran seperti pembuatan RPP yang disisipkan nilai-nilai kewirausahaan dan penerapan kurikulum life skill di dalamnya. 


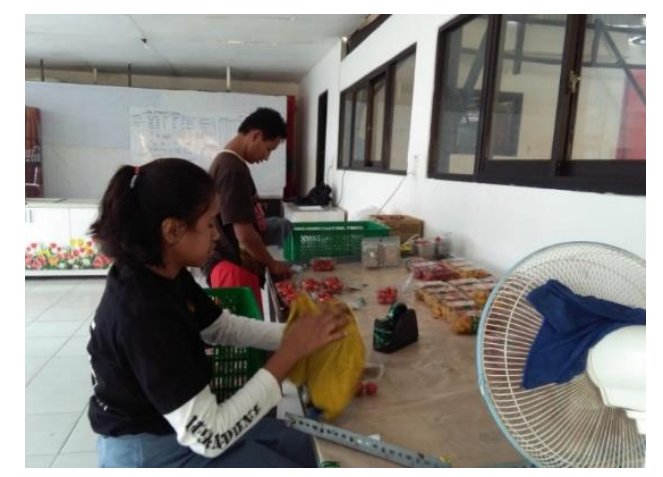

\section{Gambar 1. Siswa Melakukan Pengemasan Tomat Ceri}

Setiap siswa yang lulus dari SMA SPI diperbolehkan menjadi alumni YES (Young Entrepreneur Society) untuk mengembangkan diri dan berpartisipasi aktif dalam kegiatan praktik kewirausahaan siswa, alumni berperan sebagai guru-guru kewirausahaan siswa di laboratorium, alumni juga dianggap sebagai keluarga siswa selama berada di SMA Selamat Pagi Indonesia. Alumni SMA Selamat Pagi Indonesia dipercaya sebagai perpanjangan tangan dari kepala sekolah, kepala sekolah mempercayakan seluruh kegiatan kewirausahaan siswa pada alumni khususnya alumni yang bertugas sebagai kepala divisi. Alumni tidak hanya membina kemampuan kewirausahaan siswa tetapi juga turut mengembangkan jiwa kewirausahaan siswa. Alumni diberi kepercayaan untuk memberikan penilaian PAKSA (Pray, Attitude, Knowledge, Skill, Action) pada siswa yang dilakukan setiap minggu untuk mengetahui perkembangan siswa.

Hambatan kepala sekolah, guru dan alumni dalam pengembangan jiwa dan kemampuan kewirausahaan siswa adalah kesadaran diri siswa untuk merubah hidupnya dan tingkat kepercayaan diri siswa yang terlalu rendah atau terlalu tinggi. Sedangkan solusi dari kepala sekolah, guru, dan alumni untuk mengatasi hambatan tersebut adalah selalu memberikan evaluasi rutin, pendampingan, motivasi, dan semangat pada para siswa. Mengingatkan siswa akan tanggung jawab dan membesarkan hati mereka dan menerapkan istilah open mind atau membuka pemikiran siswa dan selalu mengingatkan siswa akan mimpi-mimpi yang ingin mereka wujudkan.

\subsection{Pembahasan}

\subsubsection{Strategi Kepala Sekolah, Guru, dan Alumni dalam Pengembangan Jiwa Kewirausahaan Siswa}

Strategi dalam mengembangkan jiwa kewirausahaan siswa oleh kepala sekolah adalah dengan pemberian motivasi. Kepala sekolah memberikan penguatan-penguatan tentang kewirausahaan, selain itu kepala sekolah menyediakan berbagai media bagi siswa untuk menjalankan SOP sesuai divisi usaha masing-masing. Kepala sekolah menerapkan program literasi wajib untuk siswa dan guru SMA Selamat Pagi Indonesia, dengan membaca buku-buku pengembangan diri diharapkan secara tidak langsung siswa dapat memiliki jiwa kepemimpinan. Strategi demikian sesuai dengan teknik-teknik yang diusulkan Maulana (2018) yaitu pengembangan diri dapat dilakukan melalui berbagai kegiatan seperti membaca, berdiskusi, pelatihan dan seminar bisnis, coaching bisnis dan lain sebagainya. Hasil temuan penelitian sesuai dengan temuan Hartani dalam Sukirman (2017) dimana jiwa kewirausahaan 
merupakan nyawa kehidupan dalam kewirausahaan yang pada prinsipnya merupakan sikap dan perilaku kewirausahaan dengan ditunjukkan melalui sifat, karakter, dan watak seseorang yang memiliki kemauan dalam mewujudkan gagasan inovatif dalam dunia nyata secara kreatif. Sifat atau karakter kewirausahaan yang nampak dalam hal ini adalah kebiasaan-kebiasaan siswa SMA Selamat Pagi Indonesia yang selalu menampakkan karakter kewirausahaan seperti berani, tidak takut mencoba, tekun dan giat berusaha.

Strategi guru untuk mengembangkan kemampuan kewirausahaan siswa adalah dengan pemberian motivasi. Hal tersebut merupakan salah satu peran guru sebagai motivator dimana seorang guru diharapkan mampu memberi semangat dan dukungan (Mulyasa, 2013b). Hasil penelitian juga sesuai dengan temuan Pulungan (2017) dimana strategi pembentukan karakter dapat dilakukan dengan kegiatan belajar mengajar di kelas dengan pendekatan integrasi mata pelajaran. Guru SMA SPI menanamkan sikap-sikap yang berkaitan dengan kewirausahaan melalui pembelajaran berbasis life skill yang diterapkan di sekolah. Selain itu guru juga selalu mengarahkan siswa untuk membaca buku-buku pengembangan sesuai dengan kebijakan sekolah. Para guru juga diharuskan untuk membaca buku pengembangan dan membuat resume buku, resume diletakkan di ruang literasi sebagai bahan bacaan untuk mempermudah para siswa pula. Temuan tersebut sesuai dengan pendapat Mulyasa (2013b) yang menyatakan peran guru sebagai pemberi inspirasi, dimana guru harus mampu menempatkan diri sebagai model bagi siswa.

Strategi dari kepala sekolah dan guru juga didukung dengan adanya strategi dari para alumni agar siswa SMA SPI dapat mengembangkan jiwa kewirausahaan yang didasarkan pada penilaian PAKSA (Pray, Attitude, Knowledge, Skill, Action) yang ada di SMA Selamat Pagi Indonesia. Sesuai dengan pendapat Nasution dalam Sukirman (2017) menyebutkan faktorfaktor yang mempengaruhi jiwa kewirausahaan seseorang diantaranya adalah kepercayaan diri, optimisme, disiplin, komitmen, berinisiatif, motivasi, memiliki jiwa kepemimpinan, suka tantangan, memiliki tanggung jawab, dan human relationship. Alumni berusaha untuk menyentuh hati para siswa dan membuka pemikiran siswa, hal ini dilakukan untuk pengembangan karakter kewirausahaan siswa. Selain itu terdapat pula sebuah dream book yang berisi tentang mimpi yang dimiliki para siswa. Hal ini merupakan salah satu bentuk motivasi agar siswa selalu semangat menjalani hidupnya dan selalu berusaha mewujudkan mimpi-mimpi tersebut. Hasil penelitian ini sesuai dengan temuan Amelia dalam Sukirman (2017) dimana jiwa kewirausahaan akan mengalami peningkatan secara signifikan terhadap kemandirian usaha secara tidak langsung dengan dimoderasi oleh perilaku kewirausahaan. Dalam hal ini alumni berperan agar para siswa memiliki perilaku kewirausahaan dengan pendekatan PAKSA yang dilakukan oleh alumni SMA Selamat Pagi Indonesia.

\subsubsection{Strategi Kepala Sekolah, Guru, dan Alumni dalam Pengembangan Kemampuan Kewirausahaan Siswa}

Kemampuan kewirausahaan akan diperoleh oleh individu ketika individu tersebut melakukan proses belajar dan membiasakan diri. Kewirausahaan menurut Suryana dalam Dewi (2016) adalah kemampuan kreatif dan inovatif yang dijadikan dasar, kiat, dan sumber daya untuk mencari peluang menuju sukses. Seseorang yang memiliki bakat kewirausahaan dapat mengembangkan bakatnya melalui pendidikan. Sesuai dengan pendapat Winarji (2008) wirausahawan secara umum dapat diartikan sebagai seseorang yang memiliki seni sehingga dapat menciptakan inovasi berkaitan dengan tujuan komersial yang telah ditentukan. 
Berdasarkan temuan penelitian strategi kepala SMA Selamat Pagi Indonesia dalam mengembangkan kemampuan kewirausahaan siswa adalah dengan membiasakan siswa untuk terjun langsung dalam praktik kewirausahaan yang ada di sekolah. Selain itu kepala sekolah juga memberikan fasilitas berupa beberapa jenis divisi usaha yang digunakan untuk mengembangkan kemampuan kewirausahaan siswa. Hal ini menunjukkan peran sekolah sebagai pendayaguna seperti halnya pendapat Hendarman (2016) dimana kepala sekolah sebagai administrator diartikan sebagai seseorang yang harus mendayagunakan dan memberdayakan sumber daya yang ada secara efektif dan efisien. Sumber daya yang ada yang dimaksud adalah pemanfaatan lahan sebagai fasilitas yang disebut sebagai laboratorium kewirausahaan.

Sedangkan strategi yang diterapkan guru dalam pembelajaran untuk mengembangkan kemampuan kewirausahaan siswa adalah dengan memberikan materi pembelajaran yang berkaitan secara langsung dengan praktik kewirausahaan. Temuan tersebut sesuai dengan paparan Warman (2013) mengenai guru harus menyiapkan perangkat pembelajaran sesuai dengan kurikulum yang berlaku. Guru SMA Selamat Pagi Indonesia memiliki tugas utama untuk mengembangkan para siswa. Temuan tersebut sesuai dengan pendapat Gunawan (2016) mengenai fungsi guru dalam pembelajaran dimana guru sedang mewujudkan fungsi instruksionalnya yang membantu siswa agar mereka dapat belajar sesuai dengan kebutuhan dan minatnya. Adanya SEL (Students Experiential Learning) juga merupakan salah satu bentuk strategi guru dalam mengaitkan materi teori dengan praktik di laboratorium sesuai dengan kebijakan sekolah. Seperti pernyataan Ciputra (2009) bahwa pendidikan berbasis kecakapan hidup dalam pelaksanaannya tidak mengubah kurikulum. Mata pelajaran yang ada di dalam kurikulum tetap berlaku, hanya saja terdapat tambahan peningkatan kreativitas dalam pelaksanaan pembelajaran.

Strategi alumni untuk mengembangkan kemampuan kewirausahaan siswa adalah dengan mengajarkan ilmu-ilmu kewirausahaan pada masing-masing divisi usaha dan penerapan SOP (Standar Operasional Prosedur) tiap divisi usaha. Selain itu terdapat penggalian bakat dan minat siswa melalui SPI Got Talent. Hasil penelitian tersebut sesuai dengan temuan Chell (2013) yang menyebutkan bahwa kemampuan itu merujuk pada bakat yang memengaruhi pemerolehan keterampilan seseorang untuk melakukan tugas tertentu, misalnya bakat musik atau kemampuan untuk memanipulasi angka, sementara keterampilan mengacu pada kemahiran dalam kinerja dan dapat ditingkatkan dengan latihan.

\subsubsection{Peran Kepala Sekolah dan Guru dalam Penerapan Pembelajaran Sistem Double Track Atau Belajar Sambil Berkarya untuk Siswa SMA Selamat Pagi Indonesia}

Dalam sistem pembelajaran double track kepala sekolah berperan sebagai penentu kebijakan kurikulum yang ada di SMA SPI. Hal ini sesuai dengan fungsi kepala sekolah sebagai pemimpin dan penentu kebijakan sesuai dengan pendapat Hendarman (2016) bahwa sebagai seorang pemimpin kepala sekolah memiliki tanggung jawab dalam melakukan perbaikan dan peningkatan mutu pendidikan dan pengajaran. SMA SPI menjadi berbeda karena selain menerapkan kurikulum akademis juga terdapat kurikulum life skill yang dibuat oleh SMA SPI sendiri. Temuan tersebut sesuai dengan pendapat Nurseto (2010) yang menyatakan bahwa pendidikan entrepreneurship dapat dimaknai sebagai pendidikan calon pengusaha agar memiliki keberanian, kemandirian, serta keterampilan sehingga meminimalkan kegagalan 
dalam usaha. Pendidikan entrepreneurship bukanlah pendidikan marketing atau penjualan yang mendidik seseorang untuk jadi pedagang, entrepreneur jauh lebih luas daripada sekedar menjadi penjual. Kepala sekolah juga menjadi penentu digunakannya penilaian PAKSA sebagai acuan pengembangan jiwa dan kemampuan kewirausahaan siswa selama berada di laboratorium. Penilaian ini dilakukan oleh alumni sebagai kepala divisi masing-masing bidang usaha terhadap siswa dengan arahan dari kepala sekolah.

Guru memiliki peran untuk membuat RPP yang didalamnya selalu disisipkan nilai-nilai kewirausahaan demi mendukung pembelajaran dengan sistem double track. Guru selalu memilah materi-materi yang akan diajarkan kepada siswa, materi harus sesuai dengan kegiatan kewirausahaan siswa di laboratorium agar siswa dapat mempraktikkan pembelajaran teori secara langsung. Hal tersebut sesuai dengan paparan Mulyasa (2013b) dimana salah satu peran guru sebagai fasilitator yang memberikan kemudahan bagi seluruh peserta didik agar dapat belajar dengan suasana menyenangkan, penuh semangat, tidak cemas, dan berani mengemukakan pendapat secara terbuka. SMA SPI tidak mengedepankan kemampuan kognitif siswa sesuai dengan konsep pendidikan berbasis kewirausahaan yang diterapkan selama ini. Hal ini berkaitan dengan strategi guru dalam pengembangan jiwa dan kemampuan kewirausahaan siswa dimana dalam setiap pembelajaran guru menanamkan nilai-nilai kewirausahaan seperti tekun, ulet, berani mengambil resiko, bertanggungjawab, dan memiliki jiwa kepemimpinan. Hasil penelitian tersebut sesuai dengan pendapat Langevelved dalam Gunawan (2016) yang menyatakan bahwa guru sebagai pendidik memberi bantuan secara sadar dan sengaja kepada seorang anak yang sedang menuju arah kedewasaan, dalam arti dapat berdiri sendiri dan bertanggungjawab susila atas segala tindakannya menurut pilihannya sendiri.

\subsubsection{Partisipasi Alumni dalam Pembelajaran Praktik Kewirausahaan Siswa di Laboratorium}

Partisipasi alumni merupakan salah satu bentuk hubungan sekolah dan masyarakat. Purwanto (2006) menyatakan bahwa terdapat tiga bentuk hubungan kerja sama antara sekolah dan masyarakat, yaitu hubungan edukatif, hubungan kultural, dan hubungan institusional. Berdasarkan temuan penelitian partisipasi alumni SMA SPI dalam pembelajaran kewirausahaan siswa sangatlah besar. Alumni bertanggung jawab dalam mendidik dan mengawasi siswa selama berada di laboratorium maupun di asrama. Alumni dianggap menjadi perpanjangan tangan dari kepala sekolah dalam mengembangkan jiwa dan kemampuan kewirausahaan kepada siswa ketika siswa tidak berada dalam kelas. Siswa seringkali menganggap bahwa alumni merupakan bagian dari keluarga mereka sendiri karena bagi siswa kakak-kakak alumni telah mengajarkan mereka banyak hal selama di laboratorium. Dalam hal ini alumni memberikan partisipasinya dalam bentuk memberikan sumbangan pelatihan dan cara kerja dalam peningkatan mutu sekolah sesuai dengan pendapat Prihatin (2011) bahwa alumni merupakan warga istimewa dan memiliki ikatan batin yang kuat dengan sekolah. Alumni diharapkan mampu turut serta berpartisipasi dalam peningkatan mutu pendidikan di sekolah. Bentuk partisipasi alumni dapat berupa sumbangan pemikiran untuk mencari konsep dan cara kerja dalam peningkatan mutu pendidikan, memberikan sumbangan pelatihan maupun informasi yang dibutuhkan sekolah. 


\subsubsection{Hambatan Kepala Sekolah, Guru, dan Alumni dalam Pengembangan Jiwa dan Kemampuan Kewirausahaan Siswa}

Kendala yang dihadapi dalam pengembangan kemampuan dan penumbuhan jiwa kewirausahaan siswa SMA Selamat Pagi Indonesia adalah kurang terbukanya pemikiran siswa terhadap apa yang dilakukan sekarang adalah bekal untuk masa depan nanti. Sedangkan kendala guru dalam mengembangkan jiwa dan kemampuan kewirausahaan siswa adalah lebih pada ketika siswa menerima pembelajaran teori dalam kelas, guru menyebutkan bahwa kendala yang dialami adalah daya tangkap siswa terhadap materi yang disampaikan tidak secepat siswa-siswa reguler sehingga perlu penjelasan lebih dalam. Kendala yang dihadapi guru adalah lebih pada penyerapan materi yang disampaikan pada siswa serta rasa kepercayaan diri yang dimiliki siswa mengingat siswa berasal dari latar belakang yang berbeda satu sama lain. Selanjutnya bagi para alumni hambatan atau kendala yang dialami alumni dalam pengembangan jiwa dan kemampuan kewirausahaan siswa SMA Selamat Pagi Indonesia adalah tentang kepercayaan diri yang dimiliki siswa, alumni berpendapat bahwa siswa sulit menemukan kepercayaan diri karena bawaan dari latar belakang masing-masing, dan perbedaan karakter siswa sehingga harus berbeda pula cara mendidiknya.

Temuan penelitian tersebut sesuai dengan pendapat Ismail (2016) bahwa faktor yang melatarbelakangi penyebab timbulnya masalah atau hambatan belajar pada siswa bersumber pada faktor internal dan faktor eksternal. Faktor internal dapat mencakup segi intelektual seperti kecerdasan, bakat, minat, motivasi, kondisi dan keadaan fisik. Faktor eksternal meliputi kondisi sosial siswa seperti lingkungan, ekonomi keluarga, sekolah dan masyarakat sekitar. Jika dikaitkan dengan temuan penelitian maka hambatan pengembangan jiwa dan kemampuan kewirausahaan siswa juga melibatkan faktor internal dan eksternal dari siswa itu sendiri.

\subsubsection{Solusi Kepala Sekolah, Guru, dan Alumni dalam Mengatasi Kendala Pengembangan Jiwa dan Kemampuan Kewirausahaan Siswa}

Untuk mengatasi hambatan kurangnya kepedulian siswa terhadap masa depan mereka kepala sekolah selalu memberikan pendekatan-pendekatan khusus agar para siswa dapat termotivasi dan terbuka pemikirannya khususnya dalam hal pengembangan jiwa dan kemampuan kewirausahaan, kepala sekolah selalu mendampingi setiap kegiatan siswa untuk mengetahui kejadian-kejadian yang terjadi dalam pengembangan jiwa dan kemampuan kewirausahaan siswa, selain itu kepala sekolah juga rutin memberikan evaluasi tentang praktik kewirausahaan yang ada di SMA Selamat Pagi Indonesia. Sedangkan solusi guru dalam mengatasi hambatan adalah dengan terus memberikan motivasi dan mengajarkan arti tanggung jawab pada siswa SMA Selamat Pagi Indonesia hal ini diterapkan untuk meningkatkan semangat dan rasa kepercayaan diri para siswa. Selain itu guru juga berusaha mengenal siswa lebih dalam lagi agar guru dapat memberikan cara yang tepat untuk menumbuhkan jiwa dan kemampuan kewirausahaan siswa. Serupa dengan kepala sekolah dan guru, alumni mengatasi hambatan yang ada dengan terus memberikan open mind atau membuka pikiran para siswa agar siswa dapat senantiasa percaya diri dalam mengembangkan dirinya.

Seperti halnya pendapat Geni dan Hidayah (2017) bahwa berbagai masalah yang ditemui di lingkungan kehidupan siswa dapat diangkat sebagai permasalahan belajar untuk dicari solusinya. Pada temuan penelitian tersebut merupakan solusi yang diberikan kepala 
sekolah, guru, dan alumni dalam pengembangan jiwa dan kemampuan kewirausahaan siswa yang termasuk dalam pembelajaran life skill SMA Selamat Pagi Indonesia. Solusi yang diberikan lebih pada pendekatan, pemberian motivasi, serta openmind pada para siswa.

\section{Simpulan}

Strategi kepala sekolah dalam mengembangkan jiwa kewirausahan siswa adalah dengan memberikan penguatan-penguatan tentang kewirausahaan. Kepala sekolah memberikan media bagi siswa untuk menjalankan SOP sesuai divisi usaha masing-masing. Terdapat kebijakan penerapan program literasi wajib untuk siswa dan guru SMA Selamat Pagi Indonesia yang diharapkan secara tidak langsung siswa dapat memiliki jiwa kepemimpinan dengan memetik pelajaran-pelajaran dari buku yang dibaca. Strategi yang digunakan guru adalah dengan pemberian motivasi yang dilakukan ketika melakukan pembelajaran di kelas. Guru SMA Selamat Pagi Indonesia menanamkan sikap-sikap yang berkaitan dengan kewirausahaan melalui pembelajaran berbasis life skill yang diterapkan di SMA Selamat Pagi Indonesia. Selain itu guru juga selalu mengarahkan siswa untuk membaca buku-buku pengembangan sesuai dengan kebijakan sekolah. Guru juga selalu menunjukkan bentuk perhatian mereka kepada para siswa salah satunya adalah membantu siswa ketika banyak pengunjung yang datang ke Transformer Center. Strategi alumni agar siswa SMA Selamat Pagi Indonesia dapat mengembangkan jiwa kewirausahaan didasarkan pada penilaian PAKSA (Pray, Attitude, Knowledge, Skill, Action) yang ada di SMA Selamat Pagi Indonesia. Namun pada tahap awal alumni melakukan pendekatan-pendekatan dengan cara merangkul para siswa agar siswa merasa nyaman. Alumni berusaha untuk menyentuh hati para siswa dan membuka pemikiran siswa, hal ini dilakukan untuk pengembangan karakter-karakter kewirausahaan siswa. Selain itu terdapat pula sebuah dream book yang berisi tentang mimpi yang dimiliki para siswa. Hal ini merupakan salah satu bentuk motivasi agar siswa selalu bersemangat menjalani hidupnya dan selalu berusaha mewujudkan mimpi-mimpi tersebut.

Strategi kepala SMA Selamat Pagi Indonesia dalam mengembangkan kemampuan kewirausahaan siswa adalah dengan membiasakan siswa untuk terjun angsung dalam praktik kewirausahaan yang ada di sekolah, selain itu kepala sekolah juga memberikan fasilitas berupa beberapa jenis divisi usaha yang digunakan untuk mengembangkan keampuan kewirausahaan siswa. Sedangkan strategi yang diterapkan guru dalam pembelajaran untuk mengembangkan kemampuan kewirausahaan siswa adalah dengan memberikan materi pembelajaran yang berkaitan secara langsung dengan praktik kewirausahaan, guru tidak memaksakan siswa agar menguasai secara utuh tentang pembelajaran yang diberikan mengingat kebijakan sekolah yang lebih mengedepankan kemampuan praktik siswa. Guru SMA Selamat Pagi Indonesia memiliki tugas utama untuk mengembangkan para siswa. Adanya SEL (Students Experiental Learning) juga merupakan salah satu bentuk strategi guru dalam mengaitkan materi teori dengan praktik di laboratorium. Strategi alumni agar siswa SMA Selamat Pagi Indonesia dapat mengembangkan kemampuan kewirausahaan mengembangkan kemampuan kewirausahaan siswa adalah dengan mengajarkan ilmu-ilmu kewirausahaan pada masing-masing divisi usaha dan penerapan SOP (Standar Operasional Prosedur) tiap divisi usaha. Selain itu agar dapat mengembangkan kemampuan kewirausahaan siswa dengan maksimal, pada tahap awal siswa diarahkan pada bidang usaha berdasarkan pengalaman di masa lalu serta bakat dan minat masing-masing siswa yang dicari pada saat memasuki masa-masa pengenalan sekolah untuk siswa baru yang dinamakan dengan SPI Got Talent. 
Dalam sistem pembelajaran double track kepala sekolah berperan sebagai penentu kebijakan kurikulum yang ada di SMA Selamat Pagi Indonesia. Kepala sekolah juga menjadi penentu digunakannya penilaian PAKSA sebagai acuan pengembangan jiwa dan kemampuan kewirausahaan siswa selama berada di laboratorium. Penilaian ini dilakukan oleh alumni sebagai kepala divisi masing-masing bidang usaha terhadap siswa dengan arahan dari kepala sekolah. Guru memiliki peran untuk membuat RPP yang didalamnya selalu disisipkan nilainilai kewirausahaan demi mendukung pembelajaran dengan sistem double track. Guru selalu memilah materi-materi yang akan diajarkan kepada siswa, materi harus sesuai dengan kegiatan kewirausahaan siswa di laboratorium agar siswa dapat mempraktikkan pembelajaran teori secara langsung. SMA Selamat Pagi Indonesia tidak mengedepankan kemampuan kognitif siswa sesuai dengan konsep pendidikan berbasis kewirausahaan yang diterapkan selama ini. Hal ini berkaitan dengan strategi guru dalam pengembangan jiwa dan kemampuan kewirausahaan siswa dimana dalam setiap pembelajaran guru menanamkan nilai-nilai kewirausahaan seperti tekun, ulet, berani mengambil resiko, dan memiliki jiwa kepemimpinan.

Partisipasi alumni SMA Selamat Pagi Indonesia dalam pembelajaran kewirausahaan siswa sangatlah besar. Alumni bertanggung jawab dalam mendidik dan mengawasi siswa selama berada di laboratorium maupun di asrama. Alumni dianggap menjadi perpanjangan tangan dari kepala sekolah dalam mengembangkan jiwa dan kemampuan kewirausahaan kepada siswa ketika siswa tidak berada dalam kelas. Para guru juga berkoordinasi dengan alumni tentang perkembangan siswa selama berada di laboratorium. Siswa seringkali menganggap bahwa alumni merupakan bagian dari keluarga mereka sendiri karena bagi siswa kakak-kakak alumni telah mengajarkan mereka banyak hal selama di laboratorium.

Kendala yang dihadapi dalam pengembangan kemampuan dan penumbuhan jiwa kewirausahaan siswa SMA Selamat Pagi Indonesia adalah kurang terbukanya pemikiran siswa terhadap apa yang dilakukan sekarang adalah bekal untuk masa depan nanti. Sedangkan kendala guru dalam mengembangkan jiwa dan kemampuan kewirausahaan siswa adalah lebih pada ketika siswa menerima pembelajaran teori dalam kelas, guru menyebutkan bahwa kendala yang dialami adalah daya tangkap siswa terhadap materi yang disampaikan tidak secepat siswa-siswa reguler sehingga perlu penjelasan lebih dalam. Kendala yang dihadapi guru adalah lebih pada penyerapan materi yang disampaikan pada siswa serta rasa kepercayaan diri yang dimiliki siswa mengingat siswa berasal dari latar belakang yang berbeda satu sama lain. Hambatan atau kendala yang dialami alumni dalam pengembangan jiwa dan kemampuan kewirausahaan siswa SMA Selamat Pagi Indonesia adalah tentang kepercayaan diri yang dimiliki siswa, alumni berpendapat bahwa siswa sulit menemukan kepercayaan diri karena bawaan dari latar belakang masing-masing, dan perbedaan karakter siswa sehingga harus berbeda pula cara mendidiknya.

Pada dasarnya baik kepala sekolah, guru, dan alumni memiliki solusi yang sama dalam mengatasi hambatan pengembangan jiwa dan kemampuan kewirausahaan. Untuk mengatasi hambatan kurangnya kepedulian siswa terhadap masa depan mereka kepala sekolah selalu memberikan pendekatan-pendekatan khusus agar para siswa dapat termotivasi dan terbuka pemikirannya khususnya dalam hal pengembangan jiwa dan kemampuan kewirausahaan, kepala sekolah juga selalu mendampingi setiap kegiatan siswa untuk mengetahui kejadiankejadian yang terjadi dalam pengembangan jiwa dan kemampuan kewirausahaan siswa, selain itu kepala sekolah juga rutin memberikan evaluasi tentang praktik-praktik kewirausahaan 
yang ada di SMA Selamat Pagi Indonesia. Sedangkan solusi guru dalam mengatasi hambatan pengembangan jiwa dan kemampuan kewirausahaan siswa adalah dengan terus memberikan motivasi dan mengajarkan arti tanggung jawab pada siswa SMA Selamat Pagi Indonesia hal ini diterapkan untuk meningkatkan semangat dan rasa kepercayaan diri para siswa. Guru juga berusaha mengenal siswa lebih dalam lagi agar guru dapat memberikan cara yang tepat untuk menumbuhkan jiwa dan kemampuan kewirausahaan siswa.Untuk solusi yang digunakan alumni dalam mengatasi hambatan pengembangan jiwa dan kemampuan kewirausahaan siswa adalah dengan terus memberikan openmind atau membuka pikiran para siswa agar siswa dapat senantiasa percaya diri dalam mengembangkan dirinya.

\section{Daftar Rujukan}

Chell, E. (2013). Review of Skill and The Entrepreneurial Process. Journal of Entrepreneurial Behavior \& Research, 19(1), 6-31.

Chotimah, C. (2014). Pendidikan Kewirausahaan di Pondok Pesantren Sidogiri Pasuruan. Jurnal Penelitian Sosial Keagamaan, 8(1), 114-136.

Dewi, N. L. A. (2015). Pengaruh Sikap Kewirausahaan Terhadap Kemampuan Mengelola Usaha pada Peserta Program Mahasiswa Wirausaha (PMW) UNDIKSHA Tahun 2015. Jurnal Program Studi Pendidikan Ekonomi, 7(2), 1-11.

Fauzi, R. \& Trihantoyo, S. (2016). Peran Kepala Sekolah dalam Implementasi Sekolah Berbasis Entrepreneurship. Jurnal Pendidikan., 4(1),1-8.

Geni, P. R. L., Hidayah, I. (2017). Kemampuan Pemecahan Masalah Siswa pada Pembelajaran Problem Based Learning Bernuansa Etnomatematika Ditinjau dari Gaya Kognitif. Journal of Mathematics Education Research, 6(1), 11-17

Gunawan, I. (2016). Manajemen Kelas. Malang: Universitas Negeri Malang.

Hakim, A. (2010). Model Pengembangan Kewirausahaan Sekolah Menengah Kejuruan (SMK) dalam Menciptakan Kemandirian Sekolah. Jurnal Riset Penelitian dan Teknologi, 4(1), 1-14

Hendarman. (2016). Revolusi Kinerja Kepala Sekolah. Jakarta: Indeks.

Hindun, I. (2005). Model Pengembangan Pendidikan Kecakapan Hidup (Life Skill) pada Sekolah Umum Tingkat Menengah di Kota Batu. Jurnal Humanity, 1(1), 29-35.

Iskandar. (2009). Metodologi Penelitian Pendidikan dan Sosial. Jakarta: Gaung Persada Press.

Ismail. (2016). Diagnosis Kesulitan Belajar Siswa dalam Pembelajaran Aktif di Sekolah. Jurnal Pendidikan, 2(1), 30-43.

Kasmir. (2014). Kewirausahaan. Jakarta: RajaGrafindo Persada

Kuntowicaksono. (2012). Pengaruh Pengetahuan Wirausaha dan Kemampuan Memecahkan Masalah Wirausaha Terhadap Minat Berwirausaha Siswa Sekolah Menengah Kejuruan. Journal of Economic Education, 1(1), 46-52.

Maulana, H. (2018). Pengembangan Jiwa Kewirausahaan: Studi Kasus Terhadap Mahasiswa yang Berwirausaha di Yogyakarta. Jurnal Ecodemica, 2(1), 24-29.

Moleong, L. J. (2011). Metodologi Penelitian Kualitatif: Edisi Revisi. Bandung: Remaja Rosdakarya.

Mulyasa. (2013). Menjadi Kepala Sekolah Profesional. Bandung: Remaja Rosdakarya.

Mulyasa. (2015). Manajemen dan Kepemimpinan Kepala Sekolah. Jakarta: Bumi Aksara.

Napitupulu, E. L. (2013). Wajib Pendidikan Kewirausahaan di SMA. Kompas. Dari https://edukasi.kompas.com/read/2013/02/27/084619882/wajib.pendidikan.kewirausahaan.di.sm a. (Online) diakses pada 16 Maret 2018

Nurseto, T. (2010). Pendidikan Berbasis Entrepreneur. Jurnal Pendidikan Akuntansi Indonesia, 8(2), 53-59.

Peraturan Pemerintah Nomor 17 Tahun 2017 tentang Perubahan Atas Peraturan Pemerintah Nomor 74 Tahun 2008 tentang Guru.

Prihatin, E. (2011). Manajemen Peserta Didik. Bandung: Alfabeta. 
Jurnal Pembelajaran, Bimbingan, dan Pengelolaan Pendidikan, 1(6), 2021, 485-494

Pulungan, A. S. (2017). Strategi Guru dalam Pembentukan Karakter Siswa di SMA Al-Hidayah Medan Tahun Ajaran 2016/2017. Skripsi, Universitas Islam Negeri Sumatera Utara.

Purwanto, N. (2006). Administrasi dan Supervisi Pendidikan. Bandung: Remaja Rosdakarya.

Sukirman. (2017). Jiwa Kewirausahaan dan Nilai Kewirausahaan Meningkatkan Kemandirian Usaha Melalui Perilaku Kewirausahaan. Jurnal Ekonomi dan Bisnis, 20(1), 119-120.

Sulistyowati, P. \& Salwa. (2016). Upaya Mengembangkan Karakter Jiwa Kewirausahaan Pada Siswa Sejak Dini Melalui Program Market Day. Jurnal Pancaran Pendidikan, 5(3), 111-120.

Usman, H. \& Raharjo, N. E. (2012). Model Pendidikan Karakter Kewirausahaan di Sekolah Menengah Kejuruan. Jurnal Pendidikan Teknologi dan Kejuruan, 21(2), 140-147.

Warman, I. \& Buwono, S., Ulfah, M. (2013). Penggunaan Perangkat Pembelajaran Guru Mata Pelajaran Kewirausahaan dalam Penerapan KTSP di SMK Mandiri Pontianak. Jurnal Pendidikan dan Pembelajaran, 2(3), 1-8.

Winarji, J. (2008). Entrepreneur \& Entrepreneurship. Jakarta: Perdana Media. 